\title{
Feasibility Analysis on the Application of Flipped Class in College English Translation Teaching Based on MOOC
}

\author{
Tingyi Chen \\ The School of Foreign Languages, Southwest Jiaotong University, Xipu 611756 \\ E-mail: yiyiyiran@163.com
}

Keywords: flipped class; college English; translation teaching; application research; MOOC;

\begin{abstract}
With the rapid development of information technology, new technologies have been popularized and applied in various industries continuously, changing people's life styles and exerting a profound impact on the teaching of colleges and universities. The main body of information dissemination of English teaching has gradually shifted from texts and images to videos, and MOOC came into being in this context. It has been verified by practice that with the aid of MOOC, a better teaching effect can be obtained. But, nowadays, many colleges and universities in our country have not given enough attention to this point, which leads to great shortage of students' English translation abilities. Based on the author's practical experience, this paper mainly analyzes the current situation and existing problems of English translation teaching in Chinese colleges and universities and the feasibility of the application of MOOC and flipped class in college English teaching.
\end{abstract}

\section{Introduction}

The information technology has been widely used in our life, changing the traditional way of production and life. As an important part of the economic and social system, colleges and universities are inevitably affected. Various advanced technology concepts are popularized in teaching activities, which makes the education level of colleges and universities progress rapidly [1] It means that higher requirements are being placed on college English teaching. The teachers should change the single teaching mode, which is based on their explanations and focuses on the training of students' translation skills, oral communication and written expression. For most of them are deeply influenced by the traditional mode of teaching, English teachers, in practical English teaching, prefer the students to know the theories well rather than improve their English comprehensive abilities. In addition, there are still a lot of shortcomings in the current English translation teaching, which leads to the shortage of students' practical English translation ability. To meet the needs of the rapid development of advanced technology and educational concept, it is of great significance to apply flipped class actively in the college English teaching. It will greatly contribute to the improvement of students' translation level and their comprehensive abilities in English learning. 


\section{The Current Situation of College English Translation Teaching in China}

Nowadays, most colleges and universities in our country do well in cultivating students' skills of listening, speaking, reading and writing in English teaching. However, a large number of teachers are greatly influenced by the traditional way of teaching, which only focuses on English grammar, syntax, vocabulary and sentence pattern and neglects the importance of practical English translation. Besides, some teachers do not have a correct understanding of translation teaching ${ }^{[2]}$. A lot of relevant exercises only include the related information of English proficiency tests, and the time used to translate for students can not be guaranteed because the translation courses are not arranged properly. Another misunderstanding of many English teachers for translation teaching is that they simply define it as the combination of listening, speaking, reading and writing skills. These existing problems in college English translation teaching have become common. It is also a drawback of college English teaching.

\section{The Significance of Flipped Class in College English Translation Teaching}

\subsection{Break the limitation of time and space in traditional classroom teaching}

The application of flipped class in current college English teaching breaks the limitation of time and space successfully for the flipped class provides a network teaching platform and a huge number of teaching resources. Students who are constrained by traditional English teaching are bounded by time and space. Under the background of MOOC, students can enjoy the freedom to study anytime and anywhere. What's more, the students in colleges and universities can study according to their own conditions and the degree of learning progress instead of having to acquire the same knowledge together with other students in the classroom at the same time. In other words, when they find it's difficult to take in the knowledge, they can get repetitive learning easily in this mode.

\subsection{Reconstruct a new English teaching model}

The fact that the traditional teaching mode has changed to the flipped classroom teaching mode means the old English classroom teaching has become extracurricular activities. In the actual English teaching, the students usually learn the theoretical part in the classroom, and then they apply the knowledge to extracurricular activities. The teachers are supposed to organize students in groups, finishing designated tasks. During this process, group discussion, cooperation and communication can help students not only acquire basic knowledge but also become the real subjects of English classroom teaching. In other words, the application of flipped class in English teaching has changed the roles of English teachers. They have been the guides of students. The students have also changed from passive learners in the past to active ones. The imperceptible changes of English teaching in colleges and universities has altered the traditional teaching mode and reconstructed the newfashioned mode of English teaching.

\section{Application of Flipped Class in College English Translation Teaching Based on MOOC}

\subsection{Change the roles of English teachers and give full play to the leading roles of college students}

In the context of MOOC, a wealth of English classroom teaching resources have sprung up on the Internet. And they also present a variety of teaching methods, which can effectively meet the 
actual needs of students at different levels. Just as its name implies, in flipped classrooms, the role exchange between teachers and students has been emphasized, that is, students, instead of the teachers, are the main body of English classroom teaching. This mode is really student-centered. English teachers, however, still lead the way of transformation and conversion. But much more abundant teaching resources and materials are provided for the flipped classes. These teaching resources not only enrich the minds of English teachers, but also broaden the visions of them. More importantly, they play a significant role in meeting the needs of college students' knowledge. With the development of Internet technology, teaching resources and materials are being greatly enriched. Facing a vast number of teaching resources, English teachers should be good at selecting from all the resources that can serve English teaching, as well as using modern technology to process the needed resources, and then showing them to students in the form of multimedia ${ }^{33]}$. Additionally, when designing teaching activities in flipped classroom, teachers should not only answer the questions raised by students in time, but also put forward empirical and creative solutions to the problems encountered by the students. What's more, MOOC provide a large number of case materials for college students, which help to improve students' practical translation abilities.

\subsection{Orientate the teaching goals and choose the contents of teaching reasonably}

In some colleges and universities, English teachers only focus on the explanation of the theoretical knowledge in the books, but ignore the improvement of students' practical English skills. The application of flipped class in college English teaching has changed these situations and clarified the directions of the future development of college English teaching. In this mode, teachers should pay more attention to the students' oral and written expression on the basis of ensuring their understanding and mastery of the basic knowledge related to English translation and oral communication. To put it in another way, teachers should make the correct orientation of the teaching objectives and choose the contents of English teaching rationally in order to improve the students' comprehensive abilities. In the past, most of English translation teaching materials came from relevant contents in out-dated English teaching materials. Thus, these teaching materials are relatively simple and lack of new ideas. The flipped classroom teaching mode based on MOOC takes these problems into account because the contents from MOOC can be updated constantly, which focuses on cultivating students' comprehensive abilities, including practical translation skills.

\subsection{Perfect the teaching management and improve the evaluation system}

In the actual college English teaching, colleges and universities should establish a perfect teaching management system and improve the evaluation system. The application of flipped classroom teaching mode not only improves the quality of English teaching in colleges and universities, but also increases the students' learning efficiency. To achieve this, colleges and universities should establish the network teaching supervision and management system actively, supervising whether the teachers use the network for practical teaching or not, and the frequency of interaction between teachers and students on the network platform, as well as the specific situations of interaction. Additionally, the establishment of English teachers' network resources should be involved in the assessment system of universities. As for the evaluation of students, English teachers should promote the development of the diversification of information process in the classroom teaching, and make data statistics on the feedback information of the students. The current conclusion is used as a reference for data collection. The teachers should also constantly enrich students' evaluation methods, and make comments on them through mutual investment, then establish a pronunciation evaluation system. 


\section{Conclusion}

To sum up, the application of flipped classroom teaching mode in college English translation teaching under the background of MOOC has improved the efficiency of students' learning greatly. In the meanwhile, various teaching materials in the form of videos also stimulates students' enthusiasm for translation teaching and arouses students' interest in college English learning effectively. Therefore, colleges and universities should attach more importance to the application of this new teaching mode, which may be the best way to benefit teachers as well as students.

\section{References}

[1] Ai Mina. The application of flipped classroom in College English translation teaching [J]. Intelligence, 2018, 10:93. [2] Guo Yuanyuan. Exploration and analysis of College English classroom teaching under the background of MOOC [J]. Upper Middle, 2017,

[3] Qu Na. Data analysis of "business translation" in flipped classroom teaching research [J]. Automation and Instrumentation, 2017, No.21307:251-252+255. 